Marcelo Zubaran Goldani 1

\title{
Maternal age, social changes, and pregnancy outcome in Ribeirão Preto, southeast Brazil, in 1978-79 and 1994
}

\author{
Idade materna, mudanças sociais e prognóstico \\ da gestação em Ribeirão Preto, Sudeste do Brasil, \\ entre 1978-79 e 1994
}

Heloisa Bettiol 1

Marco Antonio Barbieri 1

Andrew Tomkins 2

1 Departamento de Pediatria, Faculdade de Medicina de Ribeirão Preto, Universidade de São Paulo. Av. Bandeirantes 3900, Ribeirão Preto, $S P$ 14049-900, Brazil. mgoldani@fmrp.usp.br hbettiol@fmrp.usp.br 2 Centre for International Child Health, Institute of Child Health, University College of London. 30 Guilford Street, London WCIN $1 E H, U K$.

\begin{abstract}
This study focused on changes in demographic, social, and health-care patterns and pregnancy outcome related to maternal age from 1978-79 to 1994 in Ribeirão Preto, São Paulo State, Brazil. Information on pregnancy outcome was obtained from two cohorts of singleton live births, 6,681 births in 1978/79 and 2,839 births in 1994. A standardized questionnaire was submitted to mothers after delivery, and demographic information was collected from official records. There was a significant increase in teenage pregnancies (from $5.1 \%$ to $7.4 \%$ ) and a decrease in infant mortality (36/1,000 to 17/1,000). There were significant decreases in the proportion of mothers with low schooling (24.5\% to 14.4\%), smoking (28.9\% to 21.\%), and multiparity (14.7\% to 9.0\%). Prenatal coverage improved (from $23.4 \%$ to $9.0 \%$ of patients with fewer than 4 prenatal visits), while cesareans increased (from $30.6 \%$ to $50.8 \%$ ), as did preterm delivery (7.2\% to $13.6 \%)$ and low birthweight (7.2\% to $10.6 \%)$. Despite significant improvements in some maternal characteristics, the proportion of teenage pregnancies, preterm deliveries, low birthweight, and cesareans increased, raising concerns about the health costs and consequences for mothers and infants.
\end{abstract}

Key words Birth Weight; Maternal Age; Social Conditions

Resumo Foram estudadas as mudanças nos padrões demográficos, sociais e de atenção à saúde e prognóstico da gestação relacionados com a idade materna, entre 1978-79 e 1994, em Ribeirão Preto, São Paulo, Brasil. As informações sobre a gestação foram obtidas de duas coortes de recémnascidos vivos de parto único hospitalar, 6.681 nascimentos em 1978/79 e 2.839 em 1994. Um questionário padronizado foi aplicado às mães após o parto e informações demográficas foram coletadas de fontes oficiais. Houve aumento significante da gravidez na adolescência (5,1\% para 7,4\%) e decréscimo na mortalidade infantil (36/1.000 para 17/1.000). Ocorreu diminuição na proporção de mães com baixo nível educacional (24,5\% para 14,4\%), fumantes (28,9\% para 21,0\%) e multíparos (14,7\% para 9,0\%). Houve melhora na cobertura do pré-natal (23,4\% para 9,0\%, com menos de 4 consultas) e aumento de parto cesáreo (30,6\% para 50,8\%), de parto prétermo (7,2\% para 13,6\%) e de baixo peso ao nascer (7,2\% para 10,6\%). Apesar das melhorias, elevou-se a proporção de mães adolescentes, partos pré-termo, baixo peso ao nascer e cesarianas, trazendo preocupação quanto ao custo para a saúde e às conseqüências para mães e crianças.

Palavras-chave Peso ao Nascer; Idade Materna; Condições Sociais 


\section{Introduction}

Demographic changes have occurred in many countries due to the introduction of new contraceptive methods and family planning programs. In the United Kingdom, women are having their children at an older age, and the proportion of childless women in England and Wales rose by $13 \%$ in 1994 (Armitage \& Babb, 1996). Latin America has followed this same trend, with important changes in the population's age structure and reproductive patterns (Restrepo \& Rosental, 1994; Albala \& Vio, 1995).

Despite continuous population growth, the fertility rate in Brazil has decreased steadily since the 1970s. Reduced mortality and fertility led to important changes in the growth of the Brazilian population, even in the absence of well-organized family planning programs (Potts \& Crane, 1993; Aramburu, 1994; Corral, 1994).

During the last 15 years in Ribeirão Preto, one of the most highly developed areas in Latin America, situated in southeast Brazil, official data showed a $39.7 \%$ decrease in the birth rate and a $46.7 \%$ drop in the fertility rate, despite a $40.1 \%$ increase in the proportion of childbearing-age women (SEADE, 1996).

However, despite these demographic changes, there is little information on how changes in social variables like maternal education, marital status, and pregnancy outcome were involved in the process. Such an analysis can potentially foster greater understanding of the impact of demographic changes on maternal and neonatal health.

The present study aimed to investigate changes in health care, selected social variables, and pregnancy outcome according to mothers' age, using two cohort studies 15 years apart in Ribeirão Preto, São Paulo State, Brazil.

\section{Methods}

Two surveys were conducted, in 1978-79 and 1994, in Ribeirão Preto, São Paulo State, Brazil. The city had 318,496 inhabitants in 1978-79 and 461,427 in 1994. All 8 maternity hospitals in 1978-79 and 10 in 1994 were included in the studies.

From June 1978 to May 1979, all 6,681 singleton live births of resident families were included in the analysis. In 1994, since there was no seasonality of births in 1978-79 (Barbieri et al., 1989), 2,839 births were studied over a period of 4 months, from May to August 1994. Hospital delivery accounted for more than $98 \%$ of all births in both studies (SEADE, 1996).
Consent and ethical approval were obtained from all the hospitals' Clinical Directors and Ethics Committees. Neonatal anthropometric data (weight and height) were obtained shortly after delivery by trained personnel supervised by the research team. Mothers were asked to answer a standardized questionnaire on sociodemographic variables and questions related to current and previous pregnancies within 24 hours after delivery. Less than 1\% in both surveys refused to be interviewed. In 1978-79, $2.5 \%$ of the mothers were discharged from hospital before the interview, as compared to $3.2 \%$ in 1994. A minimal dataset was available from medical records in these cases. When the mother was not interviewed, data were obtained from medical records. Thus, all births were included, although some data were not found in the medical records, such as maternal age, parity, newborn gender, and type of delivery. The methodology was the same in both studies (Barbieri et al., 1989; Bettiol et al., 1998).

The following data were included in this analysis: maternal age divided into 5 groups [17 years and under = group 1 (teenage group), 18 to $19=$ group 2 (adolescent group), 20 to $29=$ group 3, 30 to $35=$ group 4,36 to $49=$ group 5]; low birth weight: newborns weighing less than 2,500 grams at birth (newborns were weighed naked using a calibrated scale with $10 \mathrm{~g}$ precision); single mothers: those living separately from the child's father; mother's low educational level: mothers with less than 4 years of schooling; parity: primiparity, mothers in their first pregnancy, and multiparity, mothers with more than 4 gestations, including the current one; maternal smoking: smoking habit regardless of the number of cigarettes per day; preterm delivery: deliveries occurring before completing gestational week 37 , as estimated by last menstrual period; cesarean section as mode of delivery; private insurance: women who had a private prepaid health care plan or who directly paid fees for services; and inadequate prenatal care: less than 4 prenatal visits. Data on infant deaths were collected from the SICAEV (System for Data Collection and Analysis of Vital Statistics) (SICAEV, 1994), the database to which all deaths in the city are reported.

In the statistical analysis, the chi-squared test was performed to assess the difference between two proportions and confidence intervals for means were calculated with correction for a finite population with a $95 \%$ confidence interval using the EpiInfo software. 


\section{Results}

The proportion of teenage mothers (group 1) showed a significant increase, from $5.1 \%$ in 1978 to $7.4 \%$ in 1994 . The proportion of mothers aged 30 to 35 years (group 4) also increased significantly, from $17.1 \%$ to $19.3 \%$ (Figure 1). Mean maternal age was similar in the two studies as a consequence of the higher proportion of teenage mothers in 1994 (Table 1).

There was a significant decrease in the proportion of mothers with low educational level, and older mothers had more schooling than younger ones in 1994, exactly the opposite of 1978. There was a significant increase in the proportion of single mothers, the highest proportion remaining in groups 1 and 2 , but this was also observed in older mothers, mainly in group 5. There was an overall decrease in smoking from 1978 to 1994 . The trend towards fewer smokers was clearer in younger groups (groups 1 and 2), with the opposite being true in older groups (Table 2 ).

Mean parity decreased from the first to the second survey (Table 1). Grand multiparity decreased as a whole, and particularly groups 4 and 5, while primiparity increased in adolescents and older mothers (Table 2).

The cesarean rate increased, becoming the most common mode of delivery by 1994 , with $50.8 \%$ of all births. The increase was similar for the 5 groups, but the highest proportion and increase occurred in group 4 (Table 2).

More women used private insurance, with groups 1 and 2 showing the greatest increase. The highest proportion of mothers with private insurance was in group 4 in both 1978 and 1994 (Table 2). The proportion of women with fewer than 4 prenatal visits declined in 1994, while the mean number of prenatal visits increased significantly (Table 1). Younger mothers (groups 1 and 2) had the poorest prenatal coverage, whereas groups 4 and 5 showed the highest increase in number of prenatal care visits (Table 2).

Infant mortality declined from 1978 to 1994 by about 50 percent in all age groups, with the largest drop in group 3. Mothers under 20 years of age remained the highest risk group for infant mortality (Table 3).

There was an increase in preterm delivery from $7.2 \%$ to $13.6 \%$ and in low birth weight from $7.2 \%$ to $10.6 \%$ from 1978 to 1994 . The most prominent increase in low birth weight and preterm delivery was in groups 4 and 5 , and the smallest increase was in group 2. Group 1 remained the highest risk group for low birth weight and preterm delivery (Table 3 ).
Figure 1

Proportion of pregnancies according to age groups in 1978/79 and 1994

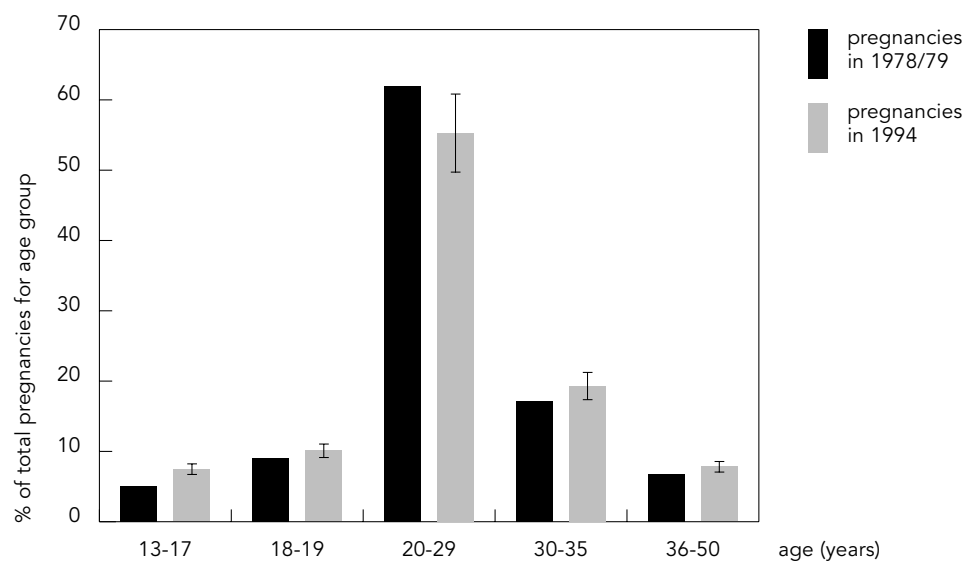

Table 1

Differences in the means of some variables between 1978/79 and 1994 .

\begin{tabular}{lrrr}
\hline Variables & $\begin{array}{r}1978 \\
\text { Mean }\end{array}$ & $\begin{array}{c}1994 \\
\text { Mean }\end{array}$ & \multicolumn{1}{c}{$\begin{array}{c}1994 \\
\text { Cl 95\% }\end{array}$} \\
\hline Number of pregnancies & 2.74 & 2.34 & $(2.08-2.40)$ \\
Maternal age (years) & 25.66 & 25.73 & $(25.51-25.96)$ \\
Gestational age (weeks) & 39.16 & 38.43 & $(38.37-38.57)$ \\
N. of prenatal visits & 5.31 & 8.76 & $(8.41-9.77)$ \\
Birth weight (grams) & 3,250 & 3,115 & $(3,092-3,133)$
\end{tabular}

\section{Discussion}

Improvements in educational level and prenatal coverage and an increase in the proportion of single mothers, together with decreased infant mortality, indicate that there have been substantial changes in lifestyle and social status in Ribeirão Preto. Furthermore, changes in fertility patterns, such as decreased multiparity, may reflect improved access to free contraceptive methods associated with improved social conditions. However, there have been increases in the prevalence of both low birth weight and preterm deliveries, despite the number of cases in which data on gestational age were unavailable.

Precision concerning gestational age has been a particularly problematic issue in obser- 
Changes in some social reproductive variables according to age groups from 1978/79 to 1994, in Ribeirão Preto - Brazil.

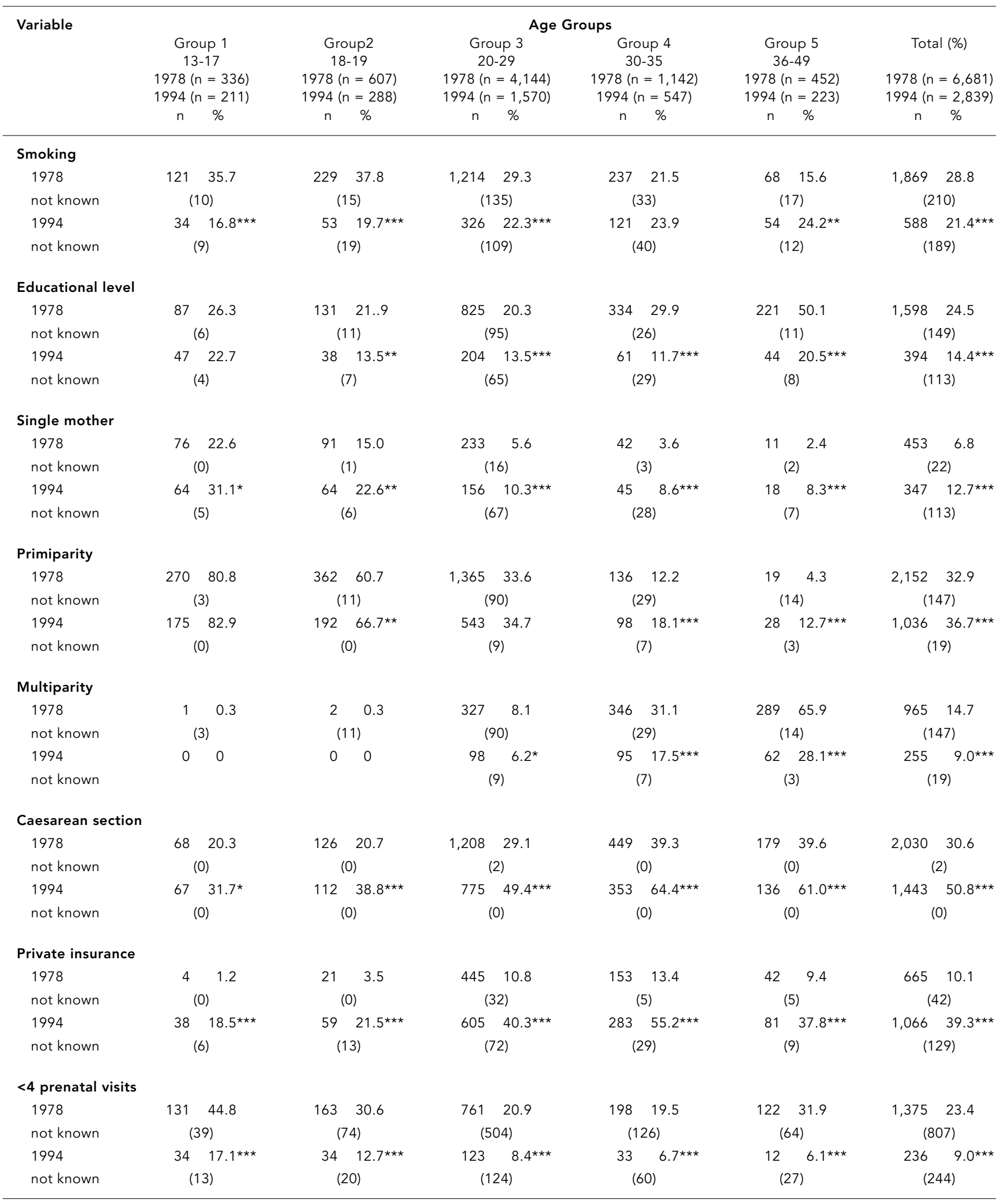

* significant $\mathrm{p}<0.05$

** significant $p<0.01$

$\star \star \star$ significant $p<0.001$ 
Changes in pregnancy outcomes according to age groups from 1978/79 to 1994, in Ribeirão Preto - Brazil.

\begin{tabular}{|c|c|c|c|c|c|c|c|}
\hline \multirow[t]{6}{*}{ Variable } & \multicolumn{7}{|c|}{ Age Groups } \\
\hline & \multirow{4}{*}{$\begin{array}{c}\text { Group } 1 \\
13-17 \\
1978(n=336) \\
1994(n=211)\end{array}$} & \multirow{2}{*}{$\begin{array}{c}\text { Group2 } \\
18-19\end{array}$} & \multicolumn{2}{|c|}{ Group 3} & Group 4 & Group 5 & Total (\%) \\
\hline & & & \multicolumn{2}{|c|}{$20-29$} & $30-35$ & $36-49$ & \multirow{2}{*}{10701401} \\
\hline & & $1978(n=607)$ & \multicolumn{2}{|c|}{$1978(n=4,144)$} & $1978(n=1,142)$ & $1978(n=452)$ & \\
\hline & & $1994(n=288)$ & \multicolumn{2}{|c|}{$1994(n=1,570)$} & $1994(n=547)$ & $1994(n=223)$ & $1994(n=2,839)$ \\
\hline & n $\%$ & n $\%$ & $\mathrm{n}$ & $\%$ & $\%$ & $\%$ & $\%$ \\
\hline \multicolumn{8}{|c|}{ Infant mortality } \\
\hline 1978 & 7.9 & 2.9 & 140 & 3.4 & 2.6 & 6.8 & 243 \\
\hline not known & (0) & (0) & \multicolumn{2}{|c|}{ (0) } & (0) & (0) & (0) \\
\hline 1994 & $\begin{array}{ll}7 & 3.3\end{array}$ & $9 \quad 3.1$ & 17 & $1.1^{* \star \star}$ & $9 \quad 1.6$ & $6 \quad 2.7^{*}$ & $48 \quad 1.7^{\star \star \star}$ \\
\hline not known & (0) & (0) & \multicolumn{2}{|c|}{ (0) } & (0) & (0) & (0) \\
\hline LBW & & & & & & & \\
\hline 1978 & $52 \quad 15.4$ & $46 \quad 7.6$ & 273 & 6.6 & 5.2 & $50 \quad 11.2$ & $480 \quad 7.2$ \\
\hline not known & (0) & (3) & $(1$ & & (5) & (3) & (25) \\
\hline 1994 & $37 \quad 17.5$ & $23 \quad 8.0$ & 140 & $8.9^{* *}$ & $6211.3^{\star \star \star}$ & $41 \quad 18.5^{\star}$ & $30310.6^{\star \star \star}$ \\
\hline not known & (0) & (1) & $(3$ & & (1) & (2) & (7) \\
\hline Preterm deliv & & & & & & & \\
\hline 1978 & $43 \quad 18.9$ & $38 \quad 11.5$ & 218 & 6.7 & $56 \quad 6.4$ & $29 \quad 9.1$ & 384 \\
\hline not known & (108) & (168) & $(89$ & & (265) & (136) & (1575) \\
\hline 1994 & $35 \quad 21.7$ & $27 \quad 11.4$ & 160 & $12.5^{\star \star \star}$ & $57 \quad 12.3^{\star \star \star}$ & $37 \quad 20 . .4^{\star \star \star}$ & $31613.6^{\star \star \star}$ \\
\hline not known & $(50)$ & (52) & $(28$ & & (85) & (42) & (517) \\
\hline
\end{tabular}

* significant $p<0.05$

** significant $p<0.01$

$\star \star \star *$ significant $p<0.001$

vational studies, mainly when a large proportion of women had too few prenatal visits, as was the case in 1978, and when the last menstrual period was used to mark the beginning of gestation (Tyson et al., 1990; Bréart et al., 1995). However, we suggest that this inherent difficulty did not discredit this study's results, since the number of mothers lacking accurate answers in general was small in both surveys. This is also valid for gestational age due to this variable's special characteristics.

The increased prevalence of low birth weight and preterm delivery, despite improvements in socioeconomic conditions and prenatal coverage, have not been restricted to Ribeirão Preto. In the city of Pelotas, in the southernmost Brazilian State of Rio Grande do Sul, preterm delivery and low birth weight rates also increased from 1982 to 1993 for no immediately apparent reason (Horta et al., 1997). In Ribeirão Preto a significant association was shown between the cesarean rate and increased prevalence of low birth weight (Silva et al., 1998). The consequences of this remain to be determined, but in the short term they could include increased childhood morbidity involving respira- tory diseases and ventricular hemorrhage, as well as hypertension, diabetes mellitus, and neuropsychological deficits in the long term (Barker, 1994; Fazzi et al., 1997).

Poor pregnancy outcome was more frequent in mothers under 18 years of age despite improvements in health care and decreased smoking, so that biological immaturity may have played an important role (Fraser et al., 1995; Olausson et al., 1997). The increase in teenage pregnancy may also reflect poor access to oral contraception and limited ability to resist social pressure for early sexual initiation associated with the lack of adequate family planning and educational programs. Hence, if the young mothers in group 1 had delayed their pregnancies for 1 or 2 years, their pregnancy outcomes might have improved, similar to group 2, which showed the lowest proportion of low birth weight and preterm deliveries.

In Ribeirão Preto, cesareans have become more common in all age groups. In the most recent national surveys, the rate increased from $31.6 \%$ in 1986 to $36.4 \%$ in 1996 (BEMFAM, 1997). This mean increase in the cesarean rate is not a nationwide phenomenon. According to a simi- 
lar study in the city of Pelotas, this trend did not occur at the same intensity there (Barros et al., 1991, 1996). In Ribeirão Preto, although biological (clinical) indications for surgery were emphasized on medical records, non-clinical factors (private hospitals, delivery time, maternal age 30 years and over, private insurance, and primiparity) were most closely associated with the likelihood of cesarean section (Gomes et al., 1999).

There was a significant decrease in the proportion of mothers who smoked, but 1 out of 5 pregnant women continued to smoke in 1994, especially older women. In the 1978 survey smoking was more common in women under 20 years old. Previous studies in Brazil have shown the prevalence of smoking in the female population to be over 29\% (Moreira et al., 1995; Horta et al., 1997). After controlling for social and biological variables, smoking had independent effects on birth weight in both surveys, despite the significant decrease in 1994 (Silva et al., 1992; Silva et al., 1998).

The data also showed an overall increase in the proportion of single mothers, consistent with other studies in both developed and developing countries (Silva et al., 1992; Arntzen et al., 1996). Groups 1 and 2 showed the highest proportion of single mothers, which may be related to low educational levels and lower socioeconomic status associated with low family support (MacDonald et al., 1992). However, for some single mothers it may reflect a personal choice.

In conclusion, demographic and social changes (including health care trends) during this period showed an interesting paradox whereby improved living conditions did not necessarily lead to better pregnancy outcomes. In addition, the lack of a health and educational policy to prevent unwanted pregnancies, plus low levels of schooling, played important roles in the increased teenage pregnancy rate. Finally, increased cesarean rates raise concerns about costs and benefits, involving the risk of iatrogenic complications in pregnancy. Thus, if the available high-level medical technology is not accompanied by consistent health care policy, it will be insufficient to improve infant and maternal health.

\section{Acknowledgments}

We wish to thank Drs. Thomas Scanlon and Susan Murray of the Institute of Child Health, London, for their helpful comments.

This study was funded by the São Paulo State Research Funding Agency (FAPESP) and the Brazilian National Council for Scientific and Technological Development (CNPq).

\section{References}

ALBALA, C. \&VIO, F., 1995. Epidemiological transition in Latin American: The case of Chile. Public Health, 109:431-442.

ARAMBURU, C., 1994. Is population policy necessary? Latin American and Andean countries. Population and Development Review, 20:159-178.

ARMITAGE, B. \& BABB, P., 1996. Population review. Population Trends, 84:7-13.

ARNTZEN, A.; MOUN, T.; MAGNUS, P. \& BAKKETEEING, L. S., 1996. Marital status as a risk factor for fetal and infant mortality. Scandinavian Journal of Social Medicine, 24:36-42.

BARBIERI, M. A.; GOMES, U. A.; BARROS FILHO, A. A.; BETTIOL, H.; ALMEIDA, L. E. A. \& SILVA, A. A. M., 1989. Saúde perinatal em Ribeirão Preto, SP, Brasil: A questão do método. Cadernos de Saúde Pública, 5:376-387.

BARKER, D. J., 1994. Outcome of low birth weight. Hormone Research, 42:223-246. 
BARROS, F. C.; VAUGHAM, J. P.; VICTORA, C. G. \& HUTTLY, R. A., 1991. Epidemic of caesarean section in Brazil. Lancet, 338:167-169.

BARROS, F. C.; VICTORA, C. G. \& MORRIS, S., 1996. Caesarean section in Brazil. Lancet, 347:839.

BEMFAM (Sociedade Civil Bem-Estar Familiar no Brasil), 1997. Pesquisa Nacional sobre Demografia e Saúde-1996. Rio de Janeiro: BEMFAM.

BETTIOL, H.; BARBIERI, M. A.; GOMES, U. A.; ANDREA, M.; GOLDANI, M. Z. \& RIBEIRO, E. R. O., 1998. Saúde perinatal em Ribeirão Preto, SP, Brasil, 1994: Metodologia e algumas características da população estudada. Revista de Saúde Pública, 32:18-28.

BRÉART, G.; BLONDEL, B.; TUPPIN, P.; GRANDJEAN, H. \& KAMINSKI, M., 1995. Did preterm deliveries continue to decrease in France in the 1980s? Paediatric and Perinatal Epidemiology, 9:296-306.

CORRAL, T., 1994. Consequences of population control programs in Brazil. Development, 1:38-40.

FAZZI, E.; ORLEIS, S.; TELESCA, C.; OMETTO, A.; RODINI, G. \& ZANZI, G., 1997. Neurodevelopmental outcome in very low birth weight infants at 24 months and 5 to 7 years of age: Changing diagnosis. Pediatric Neurology, 17:240-248.

FRASER, A. M.; BROCKERT, J. E. \& WARD, R. H., 1995. Association of young maternal age with adverse reproductive outcomes. New England Journal of Medicine, 332:1113-1117.

GOMES, U. A.; SILVA, A. A. M.; BETTIOL, H. \& BARBIERI, M. A., 1999. Risk factors for the increasing caesarean section rate in Southeast Brasil: A comparison of two birth cohorts, 1978-79 and 1994. International Journal of Epidemiology, 28:687694.

HORTA, B. L.; BARROS, F. C.; MENEZES, A. M.; HALPERN, R. \& VICTORA, C. G., 1996. Low birthweight in two population-based cohorts in southern Brazil. Cadernos de Saúde Pública, 12:27-31.

HORTA, B. L.; VICTORA, C. G.; MENEZES, A. M.; HALPERN, R. \& BARROS, F. C., 1997. Low birthweight, preterm births and intrauterine growth retardation in relation to maternal smoking. Paediatric and Perinatal Epidemiology, 11:140-151.
MacDONALD, L. D.; PEACOCK, J. L. \& ANDERSON, H. R., 1992. Marital status: Association with social and economic circumstances, psychological state and outcomes of pregnancy. Journal of Public Health Medicine, 14:26-34.

MOREIRA, L. B.; FUCHS, F. D.; MORAES, R. S.; BREDEMEIR, M. \& CARDOZO, S., 1995. Prevalence of smoking and associated factors in a metropolitan area in the southern region of Brazil. Revista de Saúde Pública, 29:46-51.

OLAUSSON, P. M. O.; CNATTINGIUS, S. \& GOLDENBERG, R. L., 1997. Determinants of poor pregnancy outcomes among teenagers in Sweden. Obstetrics \& Gynecology, 89:451-457.

POTTS, D. M. \& CRANE, S. F., 1993. Contraceptive delivery in the developing world. British Medical Bulletin, 49:27-39.

RESTREPO, H. E. \& ROSENTAL, M., 1994. The social impact of a growing population: Some major issues. Social Science and Medicine, 39:1323-1338.

SEADE (Fundação Sistema Nacional de Análises de Dados), 1996. Mulheres em Dados e São Paulo em Dados. <http://www.seade.gov.br>.

SECRETARIA MUNICIPAL DE SAÚDE/SICAEV (Sistema de Coleta de Dados e Análise de Estatísticas Vitais), 1994. Mortalidade de Residentes e não Residentes em Ribeirão Preto - 1994. Ribeirão Preto: Companhia de Desenvolvimento Econômico da Prefeitura de Ribeirão Preto.

SILVA, A. A.; BARBIERI, M. A.; GOMES, U. A. \& BETTIOL, H., 1998. Trends in low birth weight: A comparison of two birth cohorts separated by a 15year interval in Ribeirão Preto, Brazil. Bulletin of the World Health Organization, 76:73-84.

SILVA, A. A. M.; GOMES, U. A.; BETTIOL, H.; DAL BÓ, C. M. R.; MUCCILLO, G. \& BARBIERI, M. A., 1992. Associação entre idade, classe social e hábito de fumar materno com o peso ao nascer. Revista de Saúde Pública, 26:150-154.

TYSON, J.; GUZICK, D.; ROSENFELD, C. R.; LASKY, R.; GANT, N.; JIMINEZ, J. \& HEARTWELL, S., 1990. Prenatal care evaluation and cohort analyses. $P e$ diatrics, 85:195-204. 